\title{
レプリカフィルムを用いた空隙，亀裂の可視化法
}

\author{
鈴木清史*・高橋 学**
}

\section{A Visualizing Method of Pores and Cracks using Filmy Replica System}

近年のデジタル技術の向上に伴い，画像をコンピュー ターに取り込み画像処理を行う手法が各分野に扮いて実 施されている。筆者らのグループでは，これまでに岩石 内の空隙, 亀裂に樹脂を充填し作成した薄片を撮影し,

その写真をスキャナーで画像として取り込むという手 法1)で画像処理を行ってきた。この画像処理を行う過程 で一般に用いられる 2 值化は，しきい值を用いて行う ことが普通である。筆者らの場合, 空隙や亀裂に充填す る樹脂は青色であるため, スキャナーの RGB 成分のう ち B 成分を用いて分布, 密度, 形態を取り出していた。 この方法は比較的簡単に処理が行えることが特徴であ り, 解像度は写真撮影時の倍率とスキャナーに依存す る。しかしながら，岩石によっては造岩鉱物そのものの 色が空隙, 亀裂と誤認されて画像データとして取り込ま れる可能性があり，このため適用には注意が必要とされ た。このような場合，空隙，亀裂と鉱物の区別は人間の 肉眼による判定にたよるほかなく，これらを簡単に識別 できる方法が求められていた。今回，レプリカ法により 簡単に空隙, 亀裂を抽出し可視化できることが判明した ので紹介する。

レプリカ法とは, 試料表面の凹凸を皮膜形成能の良い プラスチック等に転写して, 試料表面の状態を観察する 方法である。今回用いたレプリカ材料は, 商品名 Bioden R. F. A. (応研商事株式会社) である。これはアセ チルセルロースフィルム（以下フィルムと略す）で, 大 きさは $10 \mathrm{~cm} \times 12 \mathrm{~cm}$, 厚さは $0.08 \mathrm{~mm}$ と $0.034 \mathrm{~mm}$ の 2 種がある。これは電子顕微鏡観察用で, フィルムの解

* 九州大学理学部地球惑星科学科 Department Earth and Planetary sciences, Faculty of Science, Kyushu University

** 地質調査所 Environmental Geology Department, Geological Survay of Japan

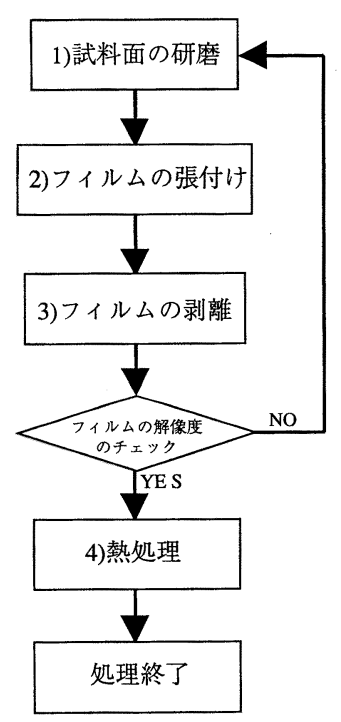

図-1＼cjkstart処理のフローチャート

像度は10 nm とされ, 空隙, 亀裂の抽出に十分な性能 を持っている。

処理は次に述べると抢りである。1)観察したい試料 の表面を研磨し平面にする。2)研磨した表面に溶剂と して酢酸メチル（Methyl acetate）を流し広げ, 気泡を 入れないように注意してフィルムを張り付ける。3)酢 酸メチルを完全に揮発させた後, フィルムを試料から引 き剥がす。4)フィルムをガラス板に挟み， $80^{\circ} \mathrm{C}$ 空気 中に30分ほど置く。3)の行程で空気圧をかけながら溶 剤を揮発させると, 気泡を押し潰し空隙や亀裂にフィル ムがより密着する。また，4)はフィルムがあるまるの を防ぐために行う。一連の処理のフローチャートを図一 1 に示す。 

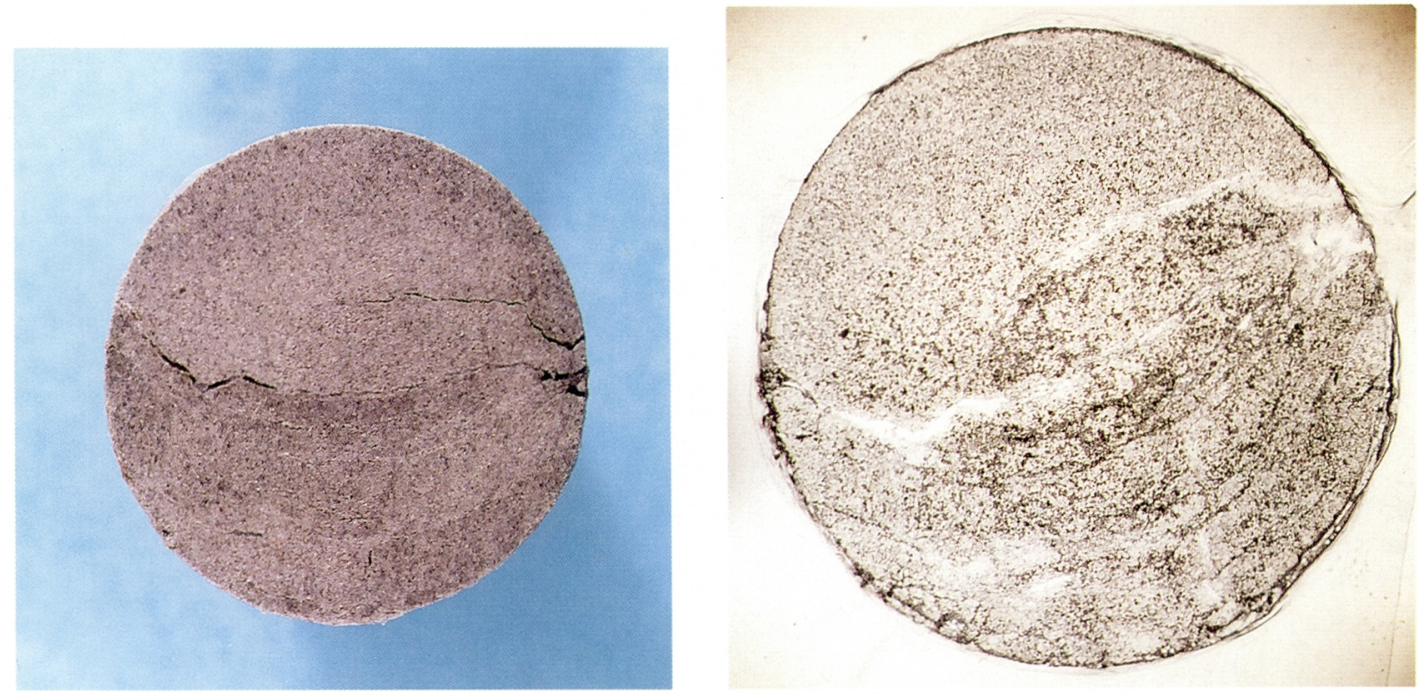

写真-1 白浜砂岩の断面（左）とレプリカフィルムの写真（右）断面の直径は $30 \mathrm{~mm}$
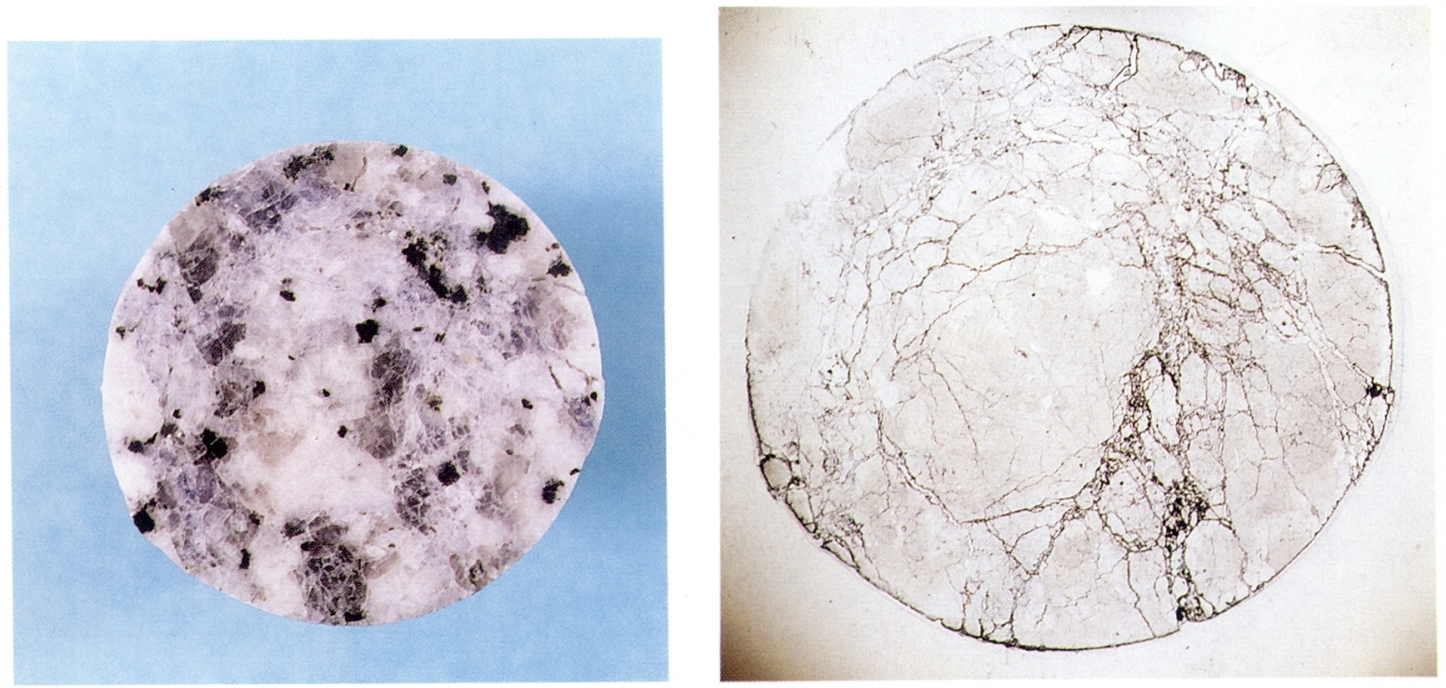

写真 -2 稲田花崗岩の断面（左）とレプリカフィルムの写真（右）断面の直径は $30 \mathrm{~mm}$.

処理を行った試料とフィルムの画像を写真 $-1,2$ に示 す。試料として用いたのは白浜砂岩と稲田花崗岩であ る。いずれも 1 軸圧縮試験終了後の供試体を切断し, $\sigma_{1}$ に垂直な断面で見たものである。試料の直径 $30 \mathrm{~mm}$, 表面の研磨は\#1,500で行った。処理により, フィルム は空隙や亀裂の部分は凸になるため, 平行光線にした透 過光を当てると光が散乱し暗くなり, それ以外の部分は 明るく観察される。

この方法は次の 2 点で有効である。すなわち，1）色 に左右されずに空隙や龟裂を抽出できること, 2)最初 から 2 值化されているため画像データーとして処理を
行いやすいことである。岩石中の空陌, 龟裂の解析は透 水や応力解析のために重要であり, 極めて簡単な処理に よって空隙や亀裂を可視化できるこの方法は, 研究を効 率よく進めるために有効な手段と考えられる。

\section{参 考 文 献}

1) 高橋 学·薛 自求·大和田朗 ·石島洋二(1992)：青色顔 料を混合した樹脂によるポアの観察について, 応用地質, Vol. 33, No. 5, pp. 294-306.

(1994年 2 月 9 日受付, 1994 年 3 月 9 日受理) 